\title{
Analisis Tenaga Bebas dan Sifat Mangkin PtRuFeNi untuk Sel Fuel Metanol Langsung (DMFC) Tunggal
}

(Analysis of Free Energy and Behaviour of PtRuFeNi Catalyst for Single Direct Methanol Fuel Cell (DMFC))

\author{
SAHRIAH BASRI* \& SITI KARTOM KAMARUDIN
}

\begin{abstract}
ABSTRAK
Mangkin dwilogam PtRu adalah mangkin konversional yang biasa digunakan untuk aplikasi sel fuel metanol langsung (DMFC). Walau bagaimanapun, kadar tindak balas pengoksidaan metanol (MOR) yang rendah menjadi kekangan yang ketara kepada penurunan prestasi dan kuasa DMFC. Kos PtRu yang sangat mahal menghalang DMFC untuk dikomersialkan yang setanding bateri. Maka, muatan PtRu dikurangkan dan logam alternatif perlu ditambah bagi memastikan prestasi DMFC dikekalkan. Justeru, objektif utama kajian ini adalah menganalisis logam alternatif yang berpotensi untuk dijadikan sebagai mangkin. Empat mangkin berpotensi iaitu ferum (Fe), nikel (Ni), aurum (Au) dan paladium (Pd) disimulasikan dengan Pt dan Ru menggunakan kaedah kimia pengkomputeran. Perisian Material Studio digunakan untuk menganalisis tenaga bebas dan tenaga penjerapan. Analisis kajian ini menemui bahawa logam ferum (Fe) dan nikel (Ni) memiliki prestasi yang sama dengan Pt dan Ru. Sel tunggal DMFC kemudian dibangunkan dengan menggunakan nanomangkin PtRuFeNi yang disokong dengan tiub nano karbon (MWCNT). Prestasi sel tunggal DMFC yang dihasilkan menggunakan

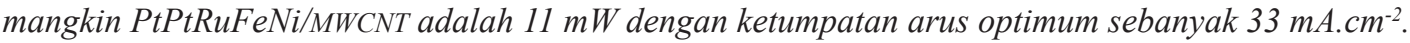

Kata kunci: Sel fuel metanol langsung; tenaga bebas; tiub nano karbon

ABSTRACT

Bimetallic PtRu catalysts is a conventional anode catalyst commonly used for direct methanol fuel cell application (DMFC). However, the low methanol oxidation reaction (MOR) rate has been a significant constraint to the DMFC performance and power output. Besides, expensive PtRu prevents DMFCs from being commercially as compare to batteries. Therefore, PtRu catalyst loading needs to be reduced and alternative metal should be added to ensure DMFC performance is maintained. Hence, the main objective of this study was to analyze potential alternative catalysts metals. Four potential catalysts, ferum ( $\mathrm{Fe}$ ), nikle (Ni), aurum (Au) and palladium (Pd) were simulated using computational chemistry. Material Studio software used to analyse free energy analysis and adsorption energy. The analysis using Material Studio software showed that the ferum (Fe) and nickel (Ni) had the same performance as Pt and Ru. Then, DMFC single cell was fabricated using PtRuFeNi nanocatalyst supported with multi -walled carbon nanotube (MWCNT) and found high DMFC performance compared to PtRu catalysts. The performance of single cell DMFC produced by PtRuFeNi/MWCNT nanocatalyst is $11 \mathrm{~mW}$ with optimum current density of $33 \mathrm{~mA} . \mathrm{cm}^{-2}$.

Keywords: Carbon nanotube; direct methanol fuel cell (DMFC); free energy

\section{PENGENALAN}

Sel fuel sangat membantu sebagai alternatif fuel selain bergantung kepada fuel tidak boleh diperbaharui. Secara umumnya, DMFC digunakan pada aplikasi sumber tenaga yang mudah alih dan bersaiz kecil (Hashim et al. 2010). Justeru, ia dapat menggantikan fungsi bateri untuk menjana tenaga. Bateri yang tidak boleh dicas semula memberikan kekangan kepada penggunaan dan menyebabkan pencemaran alam kerana terpaksa dibuang setelah digunakan. Ini merupakan faktor utama mengapa

DMFC menjadi pilihan untuk menggantikan bateri.

Kajian mangkin boleh dikategorikan kepada beberapa kategori seperti, mangkin berstruktur nano (Vrushali et al. 2018), mangkin dengan bahan campuran metal lain, mangkin tanpa platinum dan kepelbagaian bahan sokongan mangkin (Liyuan et al. 2018). Prestasi setiap jenis kajian mangkin ini adalah berbeza bergantung kepada kesan bahan yang digunakan. Mangkin berstruktur nano bertujuan untuk meningkatkan luas permukaan dan seterusnya mampu untuk meningkatkan potensi tindak balas bagi setiap mikrogram mangkin (Hongjuan et al. 2014; Zainoodin et al. 2015). Kaedah yang biasa digunakan adalah dengan menumbuhkan tiub nano karbon sebagai bahan sokongan mangkin bagi mendapatkan hasil yang lebih baik (Huimin et al. 2018). Namun, kaedah ini memerlukan kos sintesis yang tinggi. Walau bagaimanapun, kajian ini masih boleh dikembangkan lagi agar dapat meningkatkan prestasi DMFC dengan kos operasi yang rendah. Penggunaan bahan sokongan mangkin seperti tiub nano karbon dijangka dapat memberikan hasil yang sama. Selain kaedah sintesis yang lebih ringkas, ia juga menggunakan kos operasi yang murah (Subhajyoti et al. 2018). 
Mangkin bimetal seperti platinum dan rutenium mempunyai bentuk partikel nano pada keadaan biasa. Bahan sokongan seperti karbon aktif mempunyai struktur yang besar berbanding mangkin (Ahmed 2015) tidak dapat mengurangkan gumpalan mangkin Pt. Mangkin akan berkumpul di sekitar karbon menyebabkan keluasan aktif mangkin tidak dapat digunakan secara maksimum. Selain itu, Pt sebagai bahan asas dalam mangkin boleh digantikan dengan bahan lain seperti titanum bagi mengurangkan lagi kos mangkin (Prasad et al. 2015). Beberapa metod kajian yang berbeza boleh digunakan bagi sintesis mangkin jenis bukan platinum. Pemilihan bahan mangkin ditentukan dengan menjalankan kajian menggunakan perisian kimia pengkomputeran. Analisis tenaga bebas adalah salah satu kajian yang boleh digunakan sebagai asas pemilihan mangkin. Tenaga bebas yang rendah sangat berpotensi untuk meningkatkan tindak balas kerana ikatan mudah diputuskan. Tenaga yang rendah diperlukan untukk memutuskan ikatan pada metanol.

Faktor utama yang menyebabkan kinetik tindak balas rendah semasa pengoksidaan metanol di bahagian anod adalah keracunan mangkin Pt dengan kehadiran CO yang terbentuk semasa proses penyahhidrogen metanol (Mustafa et al. 2017). Oleh itu, untuk meningkatkan kecekapan DMFC, anod elektromangkin perlu bertindak balas dengan cepat semasa nyahhidrogenan metanol dan toleransi yang lebih baik. Di samping itu, sistem sokongan mangkin yang tahan lama adalah penting untuk mengekalkan prestasi DMFC. Pacuan yang tinggi untuk mengkomersilkan DMFC sebagai alat sumber kuasa mudah alih yang berpotensi telah membawa kepada pertumbuhan pesat dalam penyelidikan mangkin.

Teori fungsi ketumpatan menggunakan perisian Material Studio modul DMol3 daripada Accelrys bagi setiap simulasi yang dijalankan. Modul DMol3 merupakan salah satu program yang terpantas untuk menjalankan pengiraan DFT terutamanya bagi molekul yang bersaiz besar (Karim et al. 2014). Program ini menggunakan penghampiran elektrostatik yang unik dan proses pengoptimuman geometrinya sangat cekap. Kaedah pengkomputeran ataupun simulasi secara kajian atom dijangka lebih mudah, cepat dan tepat untuk mendapatkan hasil yang dikehendaki. Sifat bahan secara fizikal dan kimia dijadikan ukuran bagi menentukan mangkin yang terbaik. Antara bahan yang dikaji adalah $\mathrm{Pt}, \mathrm{Ru}, \mathrm{Fe}, \mathrm{Ni}$, paladium, Pd dan aurum, Au. Bahanbahan ini dipilih kerana mengambil kira faktor keaktifan elektron luar. Elektron luar ini akan berpindah semasa tindak balas dan akan membantu mempercepatkan pengaliran elektron pada lapisan mangkin. Secara teori, ferum dan nikel mempunyai elektron luar yang sangat aktif kerana memiliki tenaga atom yang sangat aktif. Maka, elektron terluar akan mudah dilepaskan dan meningkatkan ketumpatan elektron lapisan mangkin. Hal ini akan meningkatkan konduktiviti mangkin seterusnya meningkatkan kadar tindak balas mangkin. Sifat ini sangat penting bagi membantu pemindahan elektron semasa proses tindak balas.
Melalui kaedah pengkomputeran juga, kadar tenaga kinetik ditentukan (Basri et al. 2015). Daripada keputusan kajian ini, dapat diketahui secara terperinci tenaga kinetik yang digunakan semasa tindak balas berlaku. Hasil seperti tenaga bebas, tenaga penjerapan, analisis getaran frekuansi dan tenaga kinetik dapat membantu untuk mengenal pasti bahan yang terbaik untuk digunakan sebagai bahan tambahan di dalam mangkin. Bahan yang mempunyai tenaga penyerapan yang rendah adalah bahan yang terbaik kerana dapat memberikan tenaga lebihan untuk mempercepatkan proses tindak balas sama ada di anod ataupun di katod. Justeru, modul ini dipilih bagi menyelesaikan pengkomputeran dan simulasi pencirian bagi pembangunan nanomangkin untuk kajian ini.

Logam mangkin yang digunakan adalah $\mathrm{Pt}$ dan $\mathrm{Ru}$ kerana bahan ini merupakan bahan yang sangat efektif sebagai mangkin DMFC (Jiming et al. 2014). Namun, seperti yang diketahui umum, platinum merupakan logam yang mahal dan seterusnya penggunaan logam ini akan meningkatkan kos fabrikasi sel fuel. Kos mangkin hanya dapat dikurangkan dengan mengurangkan jumlah muatan Pt dan Ru. Bagi mengekalkan prestasi DFMC setelah muatan mangkin dikurangkan, logam alternatif seperti ferum, Fe, aurum, Au dan nikel, Ni perlu ditambah sebagai mangkin sokongan. Maka, objektif kajian ini adalah untuk memilih mangkin selain PtRu yang dapat membantu meningkatkan tindak balas MOR melalui analisis tenaga bebas secara kimia pengkomputeran.

\section{Metodologi}

Kajian ini menggunakan perisian Material Studio yang berasaskan pengiraan prinsip pertama yang terdapat dalam DFT. DFT merupakan kaedah simulasi kimia perkomputeran yang digunakan secara meluas. Secara asasnya, kaedah ini menentukan sifat fizik sesuatu molekul berdasarkan ketumpatan elektron.

Tindak balas di bahagian anod dikenali sebagai proses pengoksidaan metanol, MOR. Dalam proses ini, metanol akan bertindak balas dengan air bagi menghasilkan gas karbon dioksida, proton dan elektron. Walau bagaimanapun, terdapat beberapa bahan perantaraan kimia yang wujud semasa proses pengoksidaan metanol berlaku. Bahan perantaraan kimia merupakan suatu bahan kimia yang dihasilkan semasa berlakunya proses penukaran bahan tindak balas kepada hasil tindak balas. Rajah 1 menunjukkan skema gambaran bagi proses pengoksidaan di bahagian anod iaitu proses pertukaran metanol kepada gas karbon dioksida dan bahan perantaraan kimia yang mungkin wujud. Bahan perantaraan yang disenaraikan oleh Ferrin et al. (2008) akan digunakan bagi menganalisis tenaga bebas MOR.

Secara asasnya, tindak balas kimia yang berlaku di DMFC adalah seperti berikut;

Tindak balas Anod

$$
\mathrm{CH}_{3} \mathrm{OH}+\mathrm{H}_{2} \mathrm{O} \rightarrow 6 \mathrm{H}^{+}+6 \mathrm{e}^{-}+\mathrm{CO}_{2}
$$




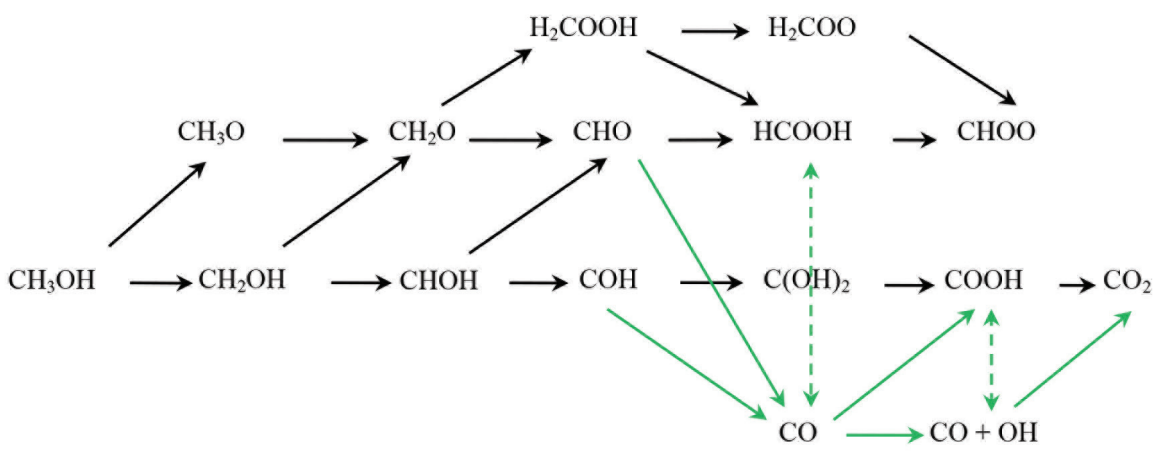

RAJAH 1. Mekanisme tindak balas pengoksidaan metanol dan bahan perantaraan

Sumber: Ferrin et al. (2008)

Tindak balas Katod

$6 \mathrm{H}^{+}+6 \mathrm{e}^{-}+3 / 2 \mathrm{O}_{2} \rightarrow 3 \mathrm{H}_{2} \mathrm{O}$

Tindak balas keseluruhan

$$
\mathrm{CH}_{3} \mathrm{OH}+3 / 2 \mathrm{O}_{2} \rightarrow 2 \mathrm{H}_{2} \mathrm{O}+\mathrm{CO}_{2}
$$

Namun, kajian ini hanya menumpukan pada pemilihan mangkin anod untuk DMFC. Justeru, mekanisme tindak balas dalam Rajah 1 diringkaskan seperti dalam (4) dan (5). Persamaan ini akan digunakan dalam kajian tenaga penjerapan untuk membandingkan hasil kajian ini dengan penyelidik luar.

$$
\begin{aligned}
& \mathrm{CH}_{3} \mathrm{OH} \rightarrow 4 \mathrm{H}^{+}+4 \mathrm{e}^{-}+\mathrm{CO}^{-} \\
& \mathrm{CO}-+\mathrm{H}_{2} \mathrm{O} \rightarrow 2 \mathrm{H}^{+}+2 \mathrm{e}^{-}+\mathrm{CO}_{2}
\end{aligned}
$$

Pengoptimuman geometri akan dilakukan terlebih dahulu sebelum analisis tenaga bebas dan tenaga penjerapan. Kemudian, mangkin yang memiliki tenaga bebas yang rendah dipilih untuk menghitung tenaga penjerapan. Semua pengoptimuman geometri, tenaga bebas dan tenaga penjerapan disimulasikan dengan kaedah DFT menggunakan teori LDA dan Fungsi Perdew-Wang $(\mathrm{PWC})$. Enam jenis mangkin dengan 12 bahan perantaraan akan simulasikan bagi membandingkan tenaga bebas dan diringkaskan dalam Jadual 1.

Bagi memastikan nanomangkin yang dibangunkan boleh diaplikasikan pada sel DMFC, seterusnya meningkatkan kadar tindak balas, sel tunggal DMFC dibangunkan dan kajian ke atas prestasi dijalankan. Perbandingan arus ketumpatan juga penting bagi mengetahui bahawa peranan mangkin yang efektif.

Fabrikasi sistem DMFC dilakukan dengan menggabungkan plat, gasket, pengumpul arus (ACC dan KCC) dan MEA dengan menggunakan skru serta disusun berdasarkan susunan seperti Rajah 2 sehingga membentuk seperti dalam Rajah 3 (Ahmad et al. 2010).

Sebelum pengujian dijalankan ke atas sistem DMFC iaitu sebelum meletakkan larutan metanol ke dalam tangki takungan, tangki takungan akan direndam dengan air suling
JADUAL 1. Logam mangkin dan bahan perantara yang akan disimulasikan menggunakan perisian Material Studio

\begin{tabular}{llc}
\hline & Bahan/Logam & Simbol \\
\hline Logam mangkin & Rutenium & $\mathrm{Ru}$ \\
& Nikel & $\mathrm{Ni}$ \\
& Ferum & $\mathrm{Fe}$ \\
Paladium & $\mathrm{Pd}$ \\
& Platinum & $\mathrm{Pt}$ \\
& Aurum & $\mathrm{Au}$ \\
Bahan perantara & $\mathrm{CH}_{3} \mathrm{O}$ & 1 \\
& $\mathrm{CH}_{2} \mathrm{OH}$ & 2 \\
& $\mathrm{CHOH}$ & 3 \\
& $\mathrm{H}_{2} \mathrm{COOH}$ & 4 \\
& $\mathrm{CHO}$ & 5 \\
& $\mathrm{COH}$ & 6 \\
& $\mathrm{H}_{2} \mathrm{COO}$ & 7 \\
$\mathrm{C}(\mathrm{OH})_{2}$ & 8 \\
$\mathrm{CO}$ & 9 \\
& $\mathrm{CHOO}$ & 10 \\
& $\mathrm{COOH}$ & 11 \\
& $\mathrm{OH}$ & 12 \\
\hline
\end{tabular}

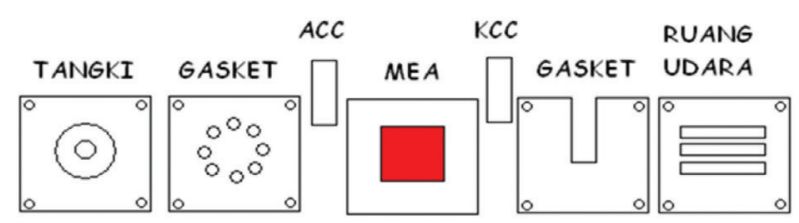

RAJAH 2. Susunan fabrikasi sistem SFML

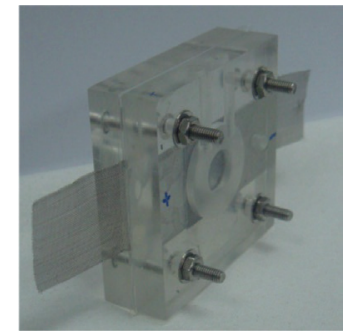

RAJAH 3. Sistem tunggal DMFC 
selama 3 min. Ujian prestasi dilakukan menggunakan $20 \mathrm{~W}$ potentiostat galvanostat. Ujian prestasi dilakukan dengan mengenakan arus secara berperingkat iaitu dengan meningkatkan nilai arus sebanyak $0.001 \mathrm{~A}$ dalam tempoh 30 s. Nilai arus ditingkatkan sehingga bacaan voltan menjadi sifar. Tempoh ujian prestasi ini bergantung kepada sistem DMFC itu sendiri.

\section{KEPUTUSAN DAN PERBINCANGAN}

Pencirian yang dijalankan terbahagi kepada tiga bahagian iaitu, pencirian tenaga bebas, tenaga penjerapan, analisis getaran dan tenaga peralihan. Analisis tenaga bebas yang dijalankan merupakan kaedah pengoptimuman kerana melalui kaedah ini, dapat dipilih mangkin yang sesuai untuk disintesis bersama Pt dan Ru dengan sokongan CNT. Nilai tenaga bebas yang rendah adalah menjadi keutamaan pemilihan mangkin. Selain itu, mangkin yang dipilih juga perlu mempunyai nilai tenaga bebas yang hampir sama dengan Pt dan Ru bagi melihat kesesuaian gabungan mangkin yang akan dihasilkan. Bagi analisis tenaga penjerapan, nilai tenaga penjerapan yang rendah amat dititk beratkan kerana ia akan memudahkan pemindahan elektron semasa proses tindak balas pengoksidaan metanol.

\section{ANALISIS TENAGA BEBAS}

Gas karbon monoksida, CO merupakan salah satu bahan perantaraan semula jadi yang terhasil semasa berlakunya proses penguraian atau pengoksidaan metanol secara tidak langsung dalam sistem DMFC. Pada masa yang sama, penghasilan gas $\mathrm{CO}$ ini mampu membawa keracunan yang tinggi kepada permukaan mangkin Pt di bahagian anod (Ferrin et al. 2008). Kesan daripada keracunan CO terhadap mangkin $\mathrm{Pt}$ akan mengurangkan pengoksidaan metanol kepada $\mathrm{CO}_{2}$, elektron yang dihasilkan akan berkurang kerana mangkin Pt akan gagal berfungsi dengan baik. Di samping itu, memandangkan mangkin jenis Pt mempunyai kos yang amat tinggi dan sukar didapati maka kajian dilakukan bagi mendapatkan potensi metal untuk meningkatkan tindak balas jika muatan mangkin Pt dikurangkan.

Oleh yang demikian, kajian dimulakan dengan melakukan simulasi terhadap setiap bahan perantaraan dalam mekanisme tindak balas di anod dengan kehadiran mangkin yang berbeza-beza. Kajian simulasi ini dijalankan bagi mengenal pasti kesan kehadiran mangkin yang berbeza-beza kepada mekanisme pengoksidaan metanol di bahagian anod dalam sistem DMFC. Di samping itu juga adalah untuk menentukan jenis mangkin yang paling mampu memberikan kesan optimum kepada kadar kinetik setiap mekanisme tindak balas dan mengenal pasti mangkin yang boleh menukarkan gas $\mathrm{CO}$ kepada $\mathrm{CO}_{2}$ dengan lebih cekap dan berkesan.

Perubahan tenaga bebas menunjukkan kecenderungan tindak balas pengoksidaan metanol pada sebelah anod. Perubahan tenaga bebas, yang juga dikenali sebagai tenaga Gibbs, boleh dihitung dengan menggunakan,

\section{$\Delta \mathrm{G}=\Delta \mathrm{H}-\mathrm{T} \Delta \mathrm{S}$}

dengan $\Delta \mathrm{H}$ ialah perubahan entalpi; $\mathrm{T}$ adalah suhu; dan $\Delta \mathrm{S}$ adalah perubahan entropi. Entalpi dan entropi nilai setiap bahan tindak balas dan produk boleh dihitung menggunakan perisian.

Secara teorinya, hasil pengoksidaan metanol melalui tindak balas tidak langsung adalah disebabkan oleh perubahan kecil dalam tenaga bebas. Oleh itu, kajian ini memberi tumpuan hanya pada tindak balas langsung. Daripada keputusan ini, semua mangkin yang memiliki tenaga bebas yang rendah menunjukkan bahawa ia sesuai bagi pengoksidaan metanol. Tenaga pertukaran metanol kepada CO yang paling rendah berlaku pada mangkin Pt. Selain itu, Fe dan Ru memiliki tenaga yang rendah dan hampir sama dengan nilai tenaga Pt.

$\mathrm{Ru}$ menunjukkan tenaga tindak balas yang paling baik untuk penukaran $\mathrm{CO}$ kepada $\mathrm{CO}_{2}$ seperti yang telah dibuktikan oleh Ozlem and Hilal (2013). Ru memiliki aktiviti elektromangkin yang sangat tinggi bagi membantu dalam persamaan 3.6. Hal ini dapat mengatasi masalah keracunan mangkin yang disebabkan oleh kehadiran CO. Walaupun Fe dan Ni mengoksidakan metanol pada kadar tindak balas lebih tinggi berbanding dengan Pt dan $\mathrm{Ru}$, keputusan yang boleh diterima berdasarkan nilai-nilai eksperimen dalam analisis elektrokimia.

Tenaga bebas boleh dihitung dengan menggunakan persamaan Arrhenius seperti berikut:

$$
\begin{aligned}
& \log j^{\circ}=\log K-\frac{\Delta G}{2.3 R T} \quad \text { atau } \\
& \Delta G=2.3 R-\frac{\partial \log j^{\circ}}{\partial\left(T^{-1}\right)}
\end{aligned}
$$

dengan $\Delta \mathrm{G}$ adalah tindak balas tenaga pengaktifan bebas atau tenaga Gibbs; R ialah pemalar gas; T ialah suhu; dan $\mathrm{K}$ adalah faktor bergantung kepada kepekatan. Satu nilai yang lebih rendah $\Delta G$ bermakna aktiviti yang lebih tinggi. Jadual 2 dan Rajah 4 menunjukkan hasil nilai tenaga bebas bagi setiap bahan perantaraan dengan kehadiran mangkin yang berbeza-beza yang diperoleh hasil daripada proses simulasi menggunakan perisian Material Studio. Didapati bahawa mangkin jenis Pt mempunyai nilai tenaga bebas yang lebih rendah bagi setiap bahan perantaraan hasil daripada proses simulasi. Justeru, mangkin jenis Pt mempunyai tahap kecekapan yang lebih tinggi dalam mempertingkatkan kadar kinetik tindak balas pada bahagian anod dalam sistem DMFC. Namun begitu, berdasarkan kepada aplikasi terkini dalam sistem DMFC didapati mangkin aloi Pt-Ru sering kali digunakan pada bahagian anod. Hal ini kerana, banyak kajian yang dilakukan menunjukkan keputusan bahawa mangkin Pt mampu meningkatkan kadar kinetik tindak balas metanol kepada karbon monoksida, manakala mangkin $\mathrm{Ru}$ pula dapat meningkatkan kadar tindak balas daripada karbon monoksida kepada karbon dioksida dengan lebih berkesan berbanding dengan mangkin lain. Kajian selanjutnya 
JADUAL 2. Nilai tenaga bebas, $\mathrm{G}(\mathrm{eV})$ bagi setiap bahan perantaraan dengan mangkin berbeza dalam pengoksidaan metanol (pada $298 \mathrm{~K}$ )

\begin{tabular}{|c|c|c|c|c|c|c|c|c|c|c|c|c|}
\hline $\begin{array}{c}\text { Bahan } \\
\text { Perantara } \\
\text { Manokin }\end{array}$ & $\mathrm{CH}_{3} \mathrm{O}$ & $\mathrm{CH}_{2} \mathrm{OH}$ & $\mathrm{CHOH}$ & $\mathrm{H}_{2} \mathrm{COOH}$ & $\mathrm{CHO}$ & $\mathrm{COH}$ & $\mathrm{H}_{2} \mathrm{COO}$ & $\mathrm{C}(\mathrm{OH})_{2}$ & $\mathrm{CO}$ & $\mathrm{CHOO}$ & $\mathrm{COOH}$ & $\mathrm{OH}$ \\
\hline \multicolumn{13}{|l|}{ Mangkin } \\
\hline $\mathrm{Ru}$ & 0.59 & 0.99 & 0.47 & 0.62 & 0.25 & 0.38 & 0.45 & 0.55 & 0.22 & 0.60 & 0.40 & 0.36 \\
\hline $\mathrm{Ni}$ & 0.91 & 0.96 & 0.99 & 1.12 & 0.72 & 0.23 & 2.15 & 1.11 & 0.24 & 0.53 & 0.43 & 0.60 \\
\hline $\mathrm{Fe}$ & 0.48 & 0.36 & 0.27 & 0.56 & 0.35 & 0.12 & 0.23 & 0.46 & 0.25 & 0.54 & 0.63 & 0.42 \\
\hline $\mathrm{Pd}$ & 0.81 & 2.05 & 1.16 & 1.69 & 0.08 & 0.83 & 1.43 & 1.37 & 0.32 & 1.66 & 1.09 & 0.51 \\
\hline $\mathrm{Pt}$ & 0.52 & 0.16 & -0.06 & 0.34 & -0.21 & -0.17 & 0.002 & 0.12 & -0.31 & 0.77 & 0.74 & 0.70 \\
\hline $\mathrm{Au}$ & 2.39 & 1.77 & 1.35 & 1.96 & 1.19 & 0.97 & 1.36 & 1.73 & 0.51 & 1.22 & 1.16 & 0.64 \\
\hline
\end{tabular}

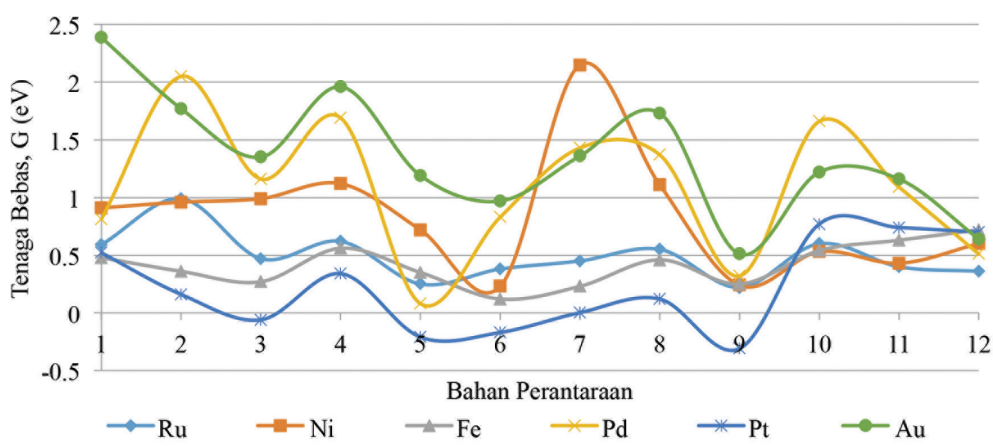

RAJAH 4. Nilai tenaga bebas, $\mathrm{G}(\mathrm{eV})$ bagi setiap bahan perantaraan dengan mangkin berbeza dalam pengoksidaan metanol (pada $298 \mathrm{~K}$ )

dijalankan bagi mengesahkan keputusan sedia ada iaitu sama ada mangkin jenis Pt atau Ru yang lebih berpotensi tinggi dalam meningkatkan kadar kinetik pengoksidaan metanol.

Berdasarkan kepada keputusan yang diperoleh menggunakan perisian Material Studio dalam Jadual 2 dan Rajah 4, didapati juga mangkin Pt mempunyai tahap kecekapan yang tinggi diikuti oleh mangkin jenis Fe, $\mathrm{Ru}$, $\mathrm{Ni}$, Pd serta Au. Keputusan ini dapat dibuktikan lagi dengan melakukan pemerhatian terhadap nilai tenaga bebas, $G$ yang lebih rendah dihasilkan oleh setiap bahan perantaraan yang menggunakan mangkin jenis Pt dalam mekanisme pengoksidaan metanol. Semakin rendah nilai tenaga bebas G yang dihasilkan, maka semakin tinggi kadar kinetik bagi mekanisme pengoksidaan metanol di anod dalam sistem DMFC. Hal ini berlaku kerana nilai tenaga bebas, $G$ yang lebih rendah akan menyumbang kepada lebihan tenaga yang lebih banyak diperoleh untuk melakukan tindak balas. Semakin rendah nilai tenaga bebas, semakin tinggi kestabilan struktur. Nilai tenaga bebas yang lebih rendah menyebabkan lebihan tenaga yang diperoleh lebih banyak. Keadaan ini mendorong kepada peningkatan kadar kinetik pengoksidaan metanol. Merujuk kepada Jadual 2, nilai tenaga bebas yang lebih rendah menunjukkan bahawa proses tersebut berlaku secara spontan. Daripada keputusan yang diperoleh dalam Rajah 4 dan Jadual 2, kaedah mengenal pasti mangkin yang mempunyai potensi tinggi dalam menukarkan gas karbon monoksida, CO kepada karbon dioksida, $\mathrm{CO}_{2}$ juga dapat ditentukan. Rajah 5 menunjukkan mekanisme pertukaran gas $\mathrm{CO}$ kepada $\mathrm{CO}_{2}$ dalam mekanisme pengoksidaan metanol dalam sistem DMFC.

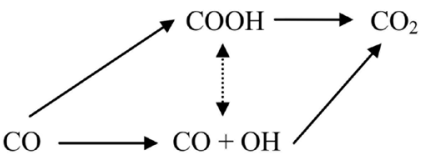

RAJAH 5. Mekanisme pertukaran CO kepada $\mathrm{CO}_{2}$

Molekul gas karbon monoksida, CO yang terbentuk dalam mekanisme secara tidak langsung ini kemudiannya akan bertindak balas dengan $\mathrm{OH}$ lalu menghasilkan $\mathrm{COOH}$ atau $\mathrm{CO}+\mathrm{OH}$. Pada umumnya, $\mathrm{OH}$ terhasil daripada proses penguraian molekul air, $\mathrm{H}_{2} \mathrm{O}$ iaitu $\mathrm{OH}$ dan $\mathrm{H}^{+}$. Seterusnya, proses pengekstrakan hidrogen daripada molekul $\mathrm{COOH}$ dan $\mathrm{CO}+\mathrm{OH}$ akan membentuk gas $\mathrm{CO}_{2}$. Oleh yang demikian, kaedah mengenal pasti jenis mangkin yang paling sesuai atau optimum dalam menukarkan gas $\mathrm{CO}$ kepada $\mathrm{CO}_{2}$ adalah bergantung kepada nilai tenaga bebas bagi bahan perantaraan jenis $\mathrm{COOH}$ dan $\mathrm{OH}$. Jadual 3 menunjukkan ringkasan nilai tenaga bebas bagi setiap bahan perantaraan $\mathrm{COOH}$ dan $\mathrm{OH}$ semasa proses pertukaran gas $\mathrm{CO}$ kepada $\mathrm{CO}_{2}$ yang diperoleh hasil daripada simulasi. Didapati mangkin Ru merupakan mangkin yang paling berkesan untuk membantu proses penukaran gas karbon monoksida, CO kepada karbon 
dioksida, $\mathrm{CO}_{2}$ dalam mekanisme pengoksidaan metanol. Hal ini disebabkan nilai tenaga bebas, $G$ bagi bahan perantaraan jenis $\mathrm{COOH}$ dan $\mathrm{OH}$ adalah paling rendah pada mangkin jenis Ru iaitu $0.40 \mathrm{eV}$ bagi $\mathrm{COOH}$ dan 0.36 $\mathrm{eV}$ bagi $\mathrm{OH}$ dan diikuti dengan jenis mangkin yang lain iaitu Ni, Fe, Pt, Pd serta Au.

Pemilihan mangkin bagi kajian ini adalah berdasarkan kaedah permodelan tenaga bebas yang telah dijalankan. Skop kajian ini akan dikecilkan dengan memilih mangkin yang paling sesuai untuk digandingkan dengan Pt dan $\mathrm{Ru}$ bagi mengurangkan kos mangkin dalam fabrikasi DMFC. Daripada keputusan ini, dapat dirumuskan bahawa mangkin yang terbaik adalah $\mathrm{Pt}, \mathrm{Ru}, \mathrm{Fe}$ dan Ni sahaja.

Bagi membuktikan kestabilan mangkin, analisis tenaga bebas selanjutnya dijalankan dengan mengambil contoh mangkin Pt. Umumnya, ikatan yang terikat kepada atom karbon adalah lebih stabil jika dibandingkan dengan ikatan yang terikat kepada atom oksigen. Hal ini kerana, keupayaan yang lebih tinggi diperlukan untuk memutuskan ikatan yang terikat pada atom karbon $(\mathrm{C}-\mathrm{X})$ berbanding oksigen (O-X) (Ferrin et al. 2008). Rajah 6 menunjukkan perbandingan tahap kestabilan bagi kedua-dua molekul iaitu $\mathrm{CH}_{3} \mathrm{O}$ dan $\mathrm{CH}_{2} \mathrm{OH}$.

Semasa proses pengoksidaan metanol, mangkin seperti Pt akan berperanan bagi mempercepatkan tindak balas. Pt akan terikat dengan molekul metanol bagi meleraikan ikatan hidrogen. Maka, melalui proses ini, atom hidrogen akan terlerai satu persatu dan akhirnya membentuk CO dan $\mathrm{CO}_{2}$ sahaja. Justeru, tenaga yang lebih rendah diperlukan bagi memudahkan proses leraian ikatan berlaku bagi membentuk $\mathrm{CO}$ dan $\mathrm{CO}_{2}$.

Berdasarkan kepada Rajah 6, didapati bahawa molekul $\mathrm{CH}_{2} \mathrm{OH}$ adalah lebih stabil berbanding dengan molekul $\mathrm{CH}_{3} \mathrm{O}$. Hal ini kerana, kehadiran mangkin dalam mekanisme pengoksidaan metanol (contohnya mangkin jenis $\mathrm{Pt}$ ) akan terikat kepada atom karbon bagi molekul $\mathrm{CH}_{2} \mathrm{OH}$ manakala bagi molekul $\mathrm{CH}_{3} \mathrm{O}$ pula mangkin $\mathrm{Pt}$ akan terikat pada atom oksigen. Memandangkan ikatan yang terikat pada atom karbon lebih sukar dileraikan maka tenaga bebas, $\mathrm{G}$ yang dihasilkan adalah lebih rendah dengan $\mathrm{G}_{\mathrm{CH} 2 \mathrm{OH}}<\mathrm{G}_{\mathrm{CH} 3 \mathrm{O}}$. Seterusnya, apabila nilai tenaga

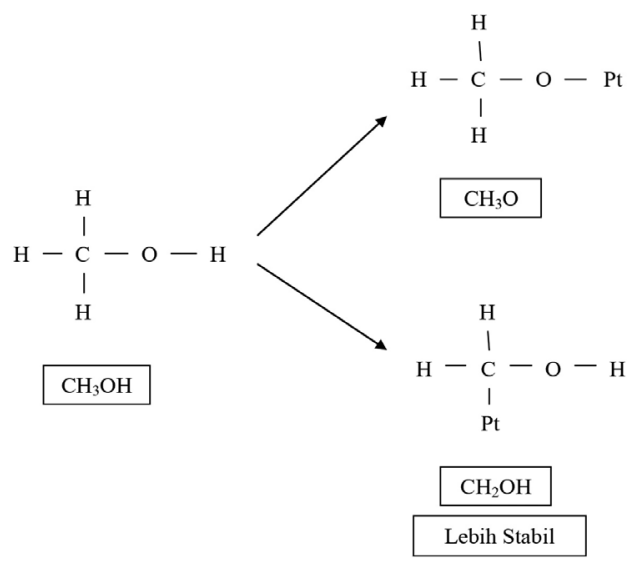

RAJAH 6. Perbandingan kestabilan struktur $\mathrm{CH}_{3} \mathrm{O}$ dan $\mathrm{CH}_{2} \mathrm{OH}$ bebas lebih rendah ini bererti molekul tersebut mempunyai lebihan tenaga yang lebih banyak untuk melakukan suatu tindak balas lalu mendorong kepada peningkatan kinetik suatu tindak balas.

Selain itu juga, ikatan mangkin (contohnya mangkin jenis $\mathrm{Pt}$ ) dengan atom karbon juga boleh menerangkan tentang kestabilan antara dua molekul iaitu $\mathrm{CHOH}$ dan $\mathrm{COH}$ (Ferrin et al. 2008). Rajah 7 menunjukkan perbandingan tahap kestabilan bagi struktur $\mathrm{CHOH}$ dan $\mathrm{COH}$ kerana Pt hanya menggunakan tenaga yang rendah untuk terikat dengan atom karbon berbanding ataom oksigen.

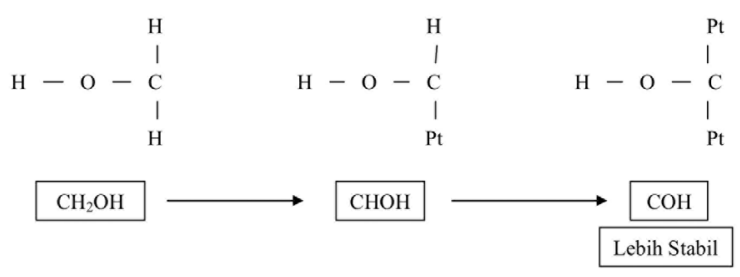

RAJAH 7. Perbandingan kestabilan struktur $\mathrm{CHOH}$ dan $\mathrm{COH}$

Merujuk kepada Rajah 7, didapati kedua-dua struktur molekul $\mathrm{CHOH}$ dan $\mathrm{COH}$ terbentuk hasil daripada penyingkiran atom hidrogen daripada ikatan karbon. Keadaan ini dapat dilihat dengan lebih jelas apabila molekul $\mathrm{CHOH}$ terbentuk hasil daripada penyingkiran hidrogen daripada atom karbon yang terdapat pada molekul $\mathrm{CH}_{2} \mathrm{OH}$. Manakala, molekul $\mathrm{COH}$ terbentuk hasil daripada penyingkiran hidrogen daripada atom karbon yang diperoleh pada molekul CHOH. Walau bagaimanapun, terdapat perbezaan antara kedua-dua struktur molekul tersebut iaitu daripada segi kestabilan dengan molekul $\mathrm{COH}$ adalah lebih stabil berbanding molekul $\mathrm{CHOH}$. Hal ini disebabkan struktur molekul $\mathrm{COH}$ yang mempunyai dua ikatan bebas yang boleh terikat kepada atom karbon manakala struktur molekul $\mathrm{CHOH}$ pula hanya mempunyai satu ikatan bebas yang boleh terikat kepada atom karbon. Rajah 7 juga menunjukkan contoh yang paling sesuai dan bagi molekul $\mathrm{CHOH}$ didapati satu mangkin Pt boleh terikat kepada atom karbon manakala bagi molekul $\mathrm{COH}$ didapati dua mangkin Pt boleh terikat kepada atom karbon. Pada umumnya, fungsi sesuatu mangkin adalah untuk membantu meningkatkan kadar kinetik sebuah mekanisme tindak balas iaitu dengan cara merendahkan tenaga pengaktifan bagi suatu tindak balas. Oleh yang demikian, semakin banyak mangkin yang terikat kepada atom karbon maka semakin tinggi tahap kestabilan sesuatu molekul tersebut. Kesimpulannya, bilangan ikatan mangkin yang terikat pada atom karbon adalah berkadar langsung dengan tahap kestabilan molekul. Semakin rendah tenaga bebas makan semakin mudah mangkin untuk terikat dengan atom karbon dan semakin banyak mangkin yang akan terikat. Hal ini akan meningkatkan kestabilan molekul membentuk $\mathrm{CO}$ dan kemudian membentuk $\mathrm{CO}_{2}$. Justeru, hasil daripada kajian tenaga bebas, selain $\mathrm{Pt}, \mathrm{Fe}$ dan $\mathrm{Ni}$ juga memiliki kestabilan yang hampir sama seperti Pt. Ru sangat stabil berbanding mangkin yang lain bagi tindak 
balas $\mathrm{CO}$ kepada $\mathrm{CO}_{2}$. Ini menunjukkan Fe dan Ni juga sesuai untuk dijadikan mangkin tambahan bagi tindak balas pengoksidaan metanol selain Pt dan Ru.

Jadual 3 dan Rajah 8 menunjukkan nilai tenaga bebas bagi setiap bahan perantaraan dengan kehadiran mangkin yang berbeza yang diperoleh hasil daripada kajian lain iaitu (Ferrin et al. 2008). Hasil kajian daripada Ferrin et al. (2008) menunjukkan bahawa mangkin Ru mempunyai keberkesanan yang lebih tinggi dalam meningkatkan kadar kinetik mekanisme pengoksidaan metanol dalam sistem DMFC sama seperti hasil yang diperoleh daripada perisian Material Studio. Hal ini berlaku kerana mangkin $\mathrm{Ru}$ menunjukkan nilai tenaga bebas, $\mathrm{G}$ yang paling rendah bagi setiap bahan perantaraan yang dikaji dalam mekanisme pengoksidaan metanol. Kestabilan yang lebih tinggi dicapai apabila nilai tenaga bebas yang lebih rendah dihasilkan. Maka keadaan ini mendorong kepada peningkatan kadar kinetik pengoksidaan metanol kerana tenaga lebihan yang lebih banyak diperoleh bagi melakukan suatu kerja atau tindak balas.

Jadual 4 dan Rajah 9 adalah perbandingan dua mangkin yang penting iaitu Pt dan Ru bagi kajian ini yang menggunakan simulasai Material studio (MS) dan kajian yang dilakukan oleh Ferrin et al. (2008). Daripada hasil keputusan ini, dapat dilihat bahawa keputusan Pt dan Ru dalam kajian ini adalah lebih stabil kerana memperoleh nilai tenaga bebas yang lebih rendah. Hal ini dipengaruhi oleh pembangunan struktur mangkin yang lebih stabil semasa pengoptimuman geometri. Namun, perbezaan ini masih dapat terima kerana perbezaan yang kecil.

JADUAL 3. Nilai tenaga bebas $\mathrm{G}(\mathrm{eV})$ semasa proses pertukaran gas karbon monoksida, $\mathrm{CO}$ kepada karbon dioksida, $\mathrm{CO}_{2}$

\begin{tabular}{ccccccc}
\hline Tenaga Bebas G $(\mathrm{eV})$ & $\mathrm{Ru}$ & $\mathrm{Ni}$ & $\mathrm{Fe}$ & $\mathrm{Pd}$ & $\mathrm{Pt}$ & $\mathrm{Au}$ \\
\hline $\mathrm{COOH}$ & 0.40 & 0.43 & 0.63 & 1.09 & 0.74 & 1.16 \\
$\mathrm{OH}$ & 0.36 & 0.60 & 0.42 & 0.51 & 0.70 & 0.64 \\
\hline
\end{tabular}

JADUAL 3. Nilai tenaga bebas, $\mathrm{G}(\mathrm{eV})$ (Ferrin et al. 2008) bagi setiap bahan perantaraan dengan mangkin berbeza dalam pengoksidaan metanol (pada $298 \mathrm{~K}$, 1bar)

\begin{tabular}{|c|c|c|c|c|c|c|c|c|c|c|c|c|}
\hline $\begin{array}{c}\text { Bahan } \\
\text { Perantara }\end{array}$ & \multirow[t]{2}{*}{$\mathrm{CH}_{3} \mathrm{O}$} & \multirow[t]{2}{*}{$\mathrm{CH}_{2} \mathrm{OH}$} & \multirow[t]{2}{*}{$\mathrm{CHOH}$} & \multirow[t]{2}{*}{$\mathrm{H}_{2} \mathrm{COOH}$} & \multirow[t]{2}{*}{$\mathrm{CHO}$} & \multirow[t]{2}{*}{$\mathrm{COH}$} & \multirow[t]{2}{*}{$\mathrm{H}_{2} \mathrm{COO}$} & \multirow[t]{2}{*}{$\mathrm{C}(\mathrm{OH})_{2}$} & \multirow[t]{2}{*}{$\mathrm{CO}$} & \multirow[t]{2}{*}{$\mathrm{CHOO}$} & \multirow[t]{2}{*}{$\mathrm{COOH}$} & \multirow[t]{2}{*}{$\mathrm{OH}$} \\
\hline Mangkin & & & & & & & & & & & & \\
\hline $\mathrm{Ru}$ & -0.08 & 0.32 & 0.50 & 0.07 & 0.02 & -0.16 & 0.48 & 0.25 & -0.65 & -0.21 & -0.10 & 0.05 \\
\hline $\mathrm{Ni}$ & 0.27 & 0.96 & 0.80 & 0.67 & 0.53 & 0.21 & 1.25 & 0.92 & -0.56 & 0.39 & 0.65 & 0.29 \\
\hline $\mathrm{Pd}$ & 1.08 & 0.63 & 0.70 & 1.28 & 0.46 & 0.26 & 2.42 & 0.65 & -0.62 & 0.79 & 0.71 & 1.04 \\
\hline $\mathrm{Pt}$ & 1.15 & 0.41 & 0.39 & 1.24 & 0.36 & 0.05 & 2.43 & 0.14 & -0.41 & 0.94 & 0.51 & 1.16 \\
\hline $\mathrm{Au}$ & 1.82 & 1.39 & 2.18 & 2.11 & 1.50 & 2.57 & 3.42 & 1.56 & 1.23 & 1.29 & 1.55 & 1.71 \\
\hline
\end{tabular}

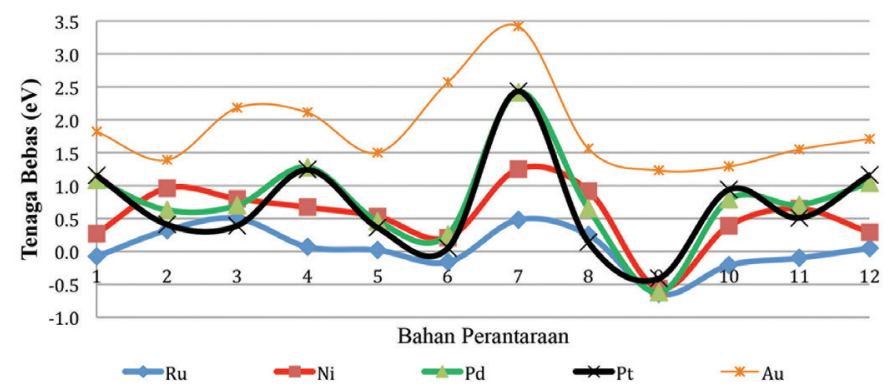

RAJAH 8. Graf nilai tenaga bebas, $\mathrm{G}(\mathrm{eV})$ melawan setiap bahan perantaraan dengan mangkin yang berbeza (Ferrin et al. 2008)

JADUAL 4. Perbandingan nilai tenaga bebas, $\mathrm{G}(\mathrm{eV})$ bagi setiap bahan perantaraan dengan mangkin berbeza hasil daripada kajian Ferrin et al. (2008) dan kajian ini (MS)

\begin{tabular}{|c|c|c|c|c|c|c|c|c|c|c|c|c|}
\hline $\begin{array}{c}\text { Bahan } \\
\text { Perantara }\end{array}$ & \multirow[t]{2}{*}{$\mathrm{CH}_{3} \mathrm{O}$} & \multirow[t]{2}{*}{$\mathrm{CH}_{2} \mathrm{OH}$} & \multirow[t]{2}{*}{$\mathrm{CHOH}$} & \multirow[t]{2}{*}{$\mathrm{H}_{2} \mathrm{COOH}$} & \multirow[t]{2}{*}{$\mathrm{CHO}$} & \multirow[t]{2}{*}{$\mathrm{COH}$} & \multirow[t]{2}{*}{$\mathrm{H}_{2} \mathrm{COO}$} & \multirow[t]{2}{*}{$\mathrm{C}(\mathrm{OH})_{2}$} & \multirow[t]{2}{*}{$\mathrm{CO}$} & \multirow[t]{2}{*}{$\mathrm{CHOO}$} & \multirow[t]{2}{*}{$\mathrm{COOH}$} & \multirow[t]{2}{*}{$\mathrm{OH}$} \\
\hline Mangkin & & & & & & & & & & & & \\
\hline $\mathrm{Ru}(\mathrm{MS})$ & 0.59 & 0.99 & 0.47 & 0.62 & 0.25 & 0.38 & 0.45 & 0.55 & 0.22 & 0.60 & 0.40 & 0.36 \\
\hline $\mathrm{Pt}(\mathrm{MS})$ & 0.52 & 0.16 & -0.06 & 0.34 & -0.21 & -0.17 & 0.002 & 0.12 & -0.31 & 0.77 & 0.74 & 0.70 \\
\hline $\mathrm{Ru}$ (Jurnal) & -0.08 & 0.32 & 0.50 & 0.07 & 0.02 & -0.16 & 0.48 & 0.25 & -0.65 & -0.21 & -0.1 & 0.05 \\
\hline Pt (Jurnal) & 1.15 & 0.41 & 0.39 & 1.24 & 0.36 & 0.05 & 2.43 & 0.14 & -0.41 & 0.94 & 0.51 & 1.16 \\
\hline
\end{tabular}




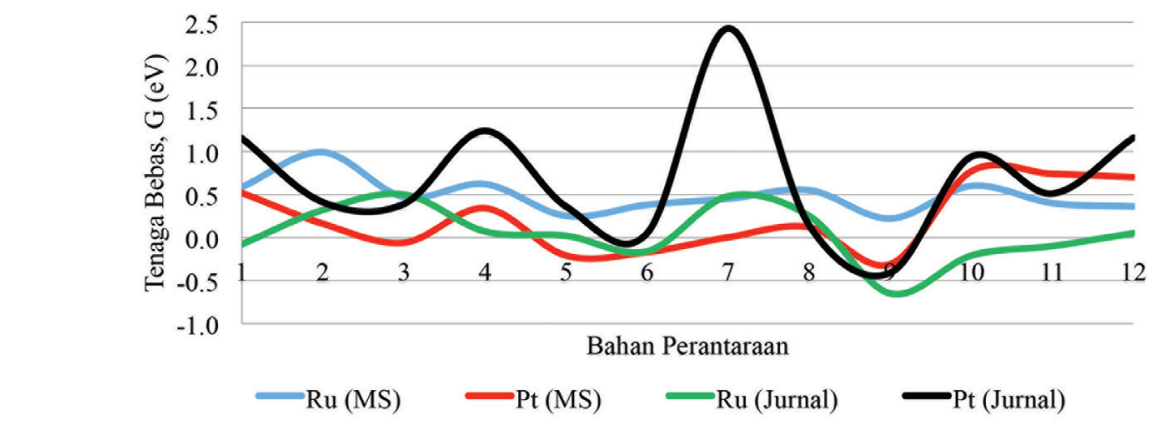

RAJAH 9. Graf perbandingan nilai tenaga bebas, $\mathrm{G}(\mathrm{eV})$ bagi setiap bahan perantaraan dengan mangkin berbeza - hasil daripada kajian Ferrin et al. (2008) dan kajian ini (MS)

Manakala, hasil kajian yang dilakukan oleh Ferrin et al. (2008) juga turut memperoleh keputusan yang sama iaitu nilai tenaga bebas bagi mangkin jenis Ru adalah paling rendah iaitu -0.10 bagi bahan perantaraan jenis $\mathrm{COOH}$ dan 0.05 bagi bahan perantaraan jenis $\mathrm{OH}$. Justeru, mangkin yang paling berkesan dalam menukarkan gas $\mathrm{CO}$ kepada $\mathrm{CO}_{2}$ adalah $\mathrm{Ru}$ dan diikuti oleh $\mathrm{Ni}, \mathrm{Pt}$, Pd serta $\mathrm{Au}$.

Ringkasan keputusan tenaga bebas adalah seperti Jadual 5 dan dibandingkan dengan keputusan daripada kajian Ferrin et al. (2008). Daripada keputusan yang diperoleh, dapat diperhatikan bahawa nilai tenaga bebas berkurang selepas tindak balas. Keputusan kajian ini membuktikan bahawa kajian ini memiliki sifat yang sama dengan keputusan yang ditunjukkan oleh Ferrin et al. (2008). Namun, secara teorinya, hasil pengoksidaan metanol melalui tindak balas bukan disebabkan oleh perubahan kecil dalam tenaga bebas (Selvarani 2009). Oleh itu, kajian ini memberi tumpuan hanya pada tindak balas langsung. Daripada keputusan ini, semua mangkin mempunyai tenaga bebas yang rendah menunjukkan bahawa ia adalah sesuai bagi metanol pengoksidaan. Penukaran tenaga paling rendah daripada metanol ke CO berlaku pada mangkin $\mathrm{Pt}$, manakala Ru dikira mempunyai tenaga tindak balas yang paling baik untuk penukaran $\mathrm{CO}$ kepada $\mathrm{CO}_{2}$. Walaupun $\mathrm{Fe}$ dan $\mathrm{Ni}$ mengoksidakan metanol pada kadar tindak balas yang lebih rendah sedikit berbanding Pt dan $\mathrm{Ru}$, keputusan Fe dan Ni setanding dengan keputusan mangkin yang lain seperti aurum dan paladium. Fe dan Ni boleh diterima berdasarkan nilainilai ujikaji dalam analisis elektrokimia.

\section{TENAGA PENJERAPAN}

Analisis tenaga penjerapan dijalankan dengan menggunakan empat jenis mangkin yang telah dipilih dalam pencirian tenaga bebas. Jadual 6 menunjukkan analisis penjerapan bagi metanol dan air dalam hubungan dengan mangkin. Ru diperhatikan mempunyai tenaga penjerapan terendah bagi tindak balas anod melibatkan metanol dan air, diikuti oleh Pt dan Fe. Jadual 6 telah menyenaraikan kemungkinan dan had bagi tenaga penjerapan setiap mangkin. Namun, Pt hanya memiliki satu nilai iaitu $17.46 \mathrm{eV}$ dan ia menunjukkan kestabilan mangkin tersebut. Teori bagi tenaga penjerapan adalah hampir sama dengan teori tenaga bebas dengan nilai tenaga yang paling rendah menunjukkan kestabilan mangkin. Justeru, mangkin yang paling stabil daripada segi tenaga penjerapan adalah mangkin yang memiliki nilai tenaga penjerapan yang rendah.

Walau bagaimanapun, Jadual 7 menunjukkan bahawa tenaga penjerapan bagi $\mathrm{Ni}$ adalah lebih rendah daripada Fe. Keputusan tambahan untuk setiap mangkin telah dicadangkan oleh modul dan pengiraan yang telah dibuat hanya untuk struktur dengan tenaga penjerapan terendah. Ini akan memastikan bahawa keputusan tenaga untuk fasa peralihan juga memberi nilai tenaga terendah. Tenaga yang rendah menunjukkan bahawa struktur optimum terbentuk mudah semasa sintesis ataupun uji kaji yang sebenar kerana tenaga yang diperlukan rendah.

Jadual 7 menunjukkan bahawa tenaga penjerapan menurun semasa proses pengoksidaan metanol. Tenaga penjerapan bagi tindak balas metanol kepada karbon monoksida yang diwakil oleh (4) adalah lebih tinggi daripada tindak balas $\mathrm{CO}$ kepada $\mathrm{CO}_{2}(5)$. Keputusan ini

JADUAL 5. Ringkasan perbandingan nilai tenaga bebas bagi nanomangkin yang dipilih

\begin{tabular}{ccccc}
\hline \multirow{2}{*}{ Tenaga bebas (eV) } & \multicolumn{2}{c}{ Kajian ini } & \multicolumn{2}{c}{ Ferrin et al. (2008) } \\
\cline { 2 - 5 } Mangkin & Persamaan (4) & Persamaan (5) & Persamaan (4) & Persamaan (5) \\
\hline $\mathrm{Pt}$ & 0.15 & -0.53 & 1.15 & 0.75 \\
$\mathrm{Ru}$ & 0.32 & -0.65 & -0.08 & -0.6 \\
$\mathrm{Fe}$ & 0.92 & 0.14 & - & - \\
$\mathrm{Ni}$ & 0.83 & 0.39 & 0.27 & 1.21 \\
\hline
\end{tabular}


JADUAL 6. Analisis tenaga penjerapan bagi setiap mangkin

Mangkin Tenaga Penjerapan, eV

JADUAL 7. Ringkasan keputusan bagi tenaga penjerapan bagi setiap mangkin untuk (4) dan (5)

\begin{tabular}{ccc}
\hline \multirow{2}{*}{ Mangkin } & \multicolumn{2}{c}{ Tenaga penjerapan tindak balas anod, eV } \\
\cline { 2 - 3 } & Persamaan $(4)$ & Persamaan $(5)$ \\
\hline $\mathrm{Pt}$ & 17.46 & $-1.97 \times 10^{5}$ \\
$\mathrm{Ru}$ & -33.01 & $-8.92 \times 10^{7}$ \\
$\mathrm{Fe}$ & 53.90 & -0.79 \\
$\mathrm{Ni}$ & 243.19 & -112.97 \\
\hline
\end{tabular}

juga menunjukkan bahawa Pt dan Ru adalah mangkin terbaik kerana mempunyai penyerapan tenaga yang rendah selepas proton dan karbon dioksida di anod dihasilkan. Tenaga penjerapan membantu dalam pemindahan elektron daripada anod ke katod. Walau bagaimanapun, untuk mengurangkan kos mangkin, ia adalah penting untuk menambah bahan alternatif yang lebih murah yang tidak mengurangkan prestasi mangkin. Ni mempunyai tenaga penjerapan lebih rendah daripada $\mathrm{Fe}$ bagi (5) manakala Fe mempunyai tenaga penjerapan yang rendah untuk (4). 
Oleh itu, dapat disimpulkan bahawa Ni dapat membantu tindak balas bagi (5) dan Fe membantu untuk (4). Ni dan $\mathrm{Fe}$ adalah bahan yang sesuai untuk digunakan sebagai mangkin bagi mengurangkan kos dan dalam masa yang sama mengekalkan prestasi.

\section{SEL TUNGGAL DMFC}

Sel tunggal difabrikasi bagi mengetahui kesan dan kesesuaian nanomangkin yang disintesis dengan sel fuel metanol langsung. Sebelum pengujian dijalankan ke atas sistem DMFC iaitu sebelum meletakkan larutan metanol ke dalam tangki takungan, tangki takungan akan direndam dengan air suling selama 3 min. Ujian Voltan Litar Terbuka (OCV) dan prestasi dilakukan menggunakan 20 W potentiostat galvanostat. Pengujian OCV dilakukan pada litar terbuka tanpa dikenakan beban iaitu arus. Ia dilakukan sebaik sahaja larutan metanol berinteraksi dengan elektrod dan akan dioperasikan sehingga bacaan voltan sistem menjadi stabil iaitu lebih kurang dalam 8 jam bagi satu unit sistem tunggal. Masa bagi sistem DMFC menunjukkan nilai kestabilan voltan akan diperoleh daripada pengujian OCV. Masa tersebut akan digunakan bagi menjalankan ujian prestasi iaitu pada nilai voltan yang stabil. Ujian prestasi dilakukan dengan mengenakan arus secara berperingkat iaitu dengan meningkatkan nilai arus sebanyak 0.001 A dalam tempoh $30 \mathrm{~s}$. Nilai arus ditingkatkan sehingga bacaan voltan manjadi sifar. Tempoh ujian prestasi ini bergantung kepada sistem DMFC itu sendiri. Ujian ketumpatan arus dijalankan dan dibandingkan dengan penyelidik luar. Perbandingan ketumpatan arus sangat penting bangi mengenal pasti peningkatan kadar tindak balas dalam lapisan mangkin.
Rajah 10 menunjukkan keputusan prestasi sel tunggal menggunakan nanomangkin PtRuFeNi/MWCNT. Ketumpatan arus optimum yang diperoleh adalah 33 mA. $\mathrm{cm}^{-2}$ dan kuasa maksimum yang boleh dicapai adalah $11 \mathrm{~mW}$. Keputusan ketumpatan arus yang diperoleh ini adalah sama seperti keputusan ketumpatan arus yang diperoleh dalam sel separa yang dibangunkan melalui pencirian kitaran voltametri, CV iaitu 31 mA.mg ${ }^{-1}$. Keputusan ini juga adalah setanding dengan keputusan prestasi nanomangkin yang dibangunkan oleh penyelidik lain. Ini menunjukkan bahawa, struktur yang dibangunkan dapat menghasilkan mangkin yang lebih baik daripada segi struktur dan kos yang lebih murah berbanding mangkin konvensional. Justeru, dapat disimpulkan bahawa nanomangkin PtRuFeNi/MWCNT sesuai digunakan sebagai mangkin bagi sel fuel metanol langsung dan dapat menyelesaikan masalah kinetik tindak balas yang rendah serta kos mangkin yang tinggi.

Ketumpatan arus adalah pertimbangan utama bagi prestasi DMFC. Hal ini ketumpatan arus merupakan pengukur kepada prestasi bagi setiap jenis nanomangkin seperti yang telah diterangkan sebelum ini. Justeru, dalam kajian ini kami juga membandingkan keputusan ketumpatan arus dengan penyelidik yang lain seperti yang ditunjukkan dalam Jadual 8 . Tiga penyelidik ini dipilih kerana menggunakan muatan mangkin PtRu yang sama iaitu $2.0 \mathrm{mg} / \mathrm{cm}^{2}$. Dapat diperhatikan bahawa, nanomangkin PtRuFeNi/MWCNT kajian ini dapat menghasilkan ketumpatan arus yang lebih tinggi daripada penyelidik lain.

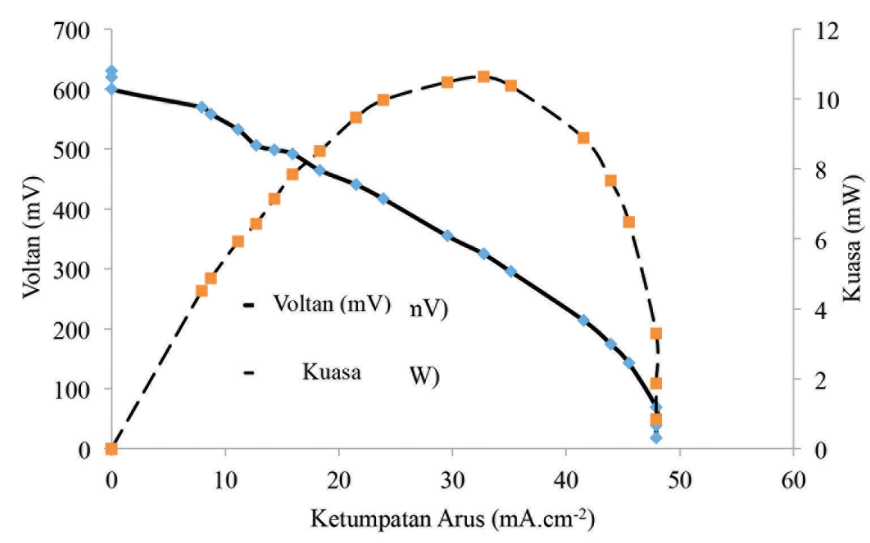

RAJAH 10. Keputusan prestasi sel tunggal SFML

JADUAL 8. Perbandingan keputusan dengan kajian ini dengan penyelidik lain

\begin{tabular}{lcc}
\hline Penyelidik & Nanomangkin & Ketumpatan Arus, mA.mg ${ }^{-1}$ \\
\hline Kajian ini & PtRuFeNi/MWCNT & 31 \\
Kajian ini & PtRuNi/MWCNT & 28 \\
Guo (2005) & PtRu/C & 20 \\
Jeon (2007) & PtRuFe/MWCNT & 5.67 \\
Liu (2008) & PtRuNi/C & 9.0 \\
\hline
\end{tabular}




\section{KESIMPULAN}

Kajian ini telah menganalisis tenaga bebas dan tenaga penjerapan bagi pemilihan mangkin untuk tindak balas MOR dalam sistem DMFC. Kaedah kimia pengkomputeran ataupun simulasi telah digunakan bagi mendapatkan bahan mangkin yang sesuai digunakan bagi tindak balas pengoksidaan metanol. Kaedah tersebut menganalisis tenaga bebas dan didapati platinum, rutenium, ferum dan nikel sangat menepati ciri-ciri mangkin yang dikehendaki iaitu tenaga bebas yang rendah. Justeru, pencirian seterusnya adalah dengan mengenal pasti kesesuaian mangkin yang dipilih melalui analisis tenaga penjerapan. Analisis tenaga penjerapan menunjukkan bahawa keduadua mangkin ferum, Fe dan nikel, Ni juga rendah dan setanding dengan mangkin dwilogam Pt dan Ru. Prestasi sel tunggal DMFC yang dihasilkan menggunakan mangkin PtPtRuFeNi/MWCNT adalah $11 \mathrm{~mW}$ dengan ketumpatan arus optimum sebanyak $33 \mathrm{~mA} . \mathrm{cm}^{-2}$. Ujian $\mathrm{CV}$ juga menghasilkan keputusan yang sama seperti keputusan prestasi sel tunggal iaitu $31 \mathrm{~mA}^{\mathrm{mg}}{ }^{-1}$. Selain itu, ia juga setanding dengan prestasi DMFC bagi penyelidk yang lain. Hal ini membuktikan bahawa nanomangkin yang dihasilkan boleh diaplikasikan pada DMFC. Penambahan logam seperti Fe dan Ni serta aplikasi tiub nano karbon dapat meningkatkan prestasi DMFC di samping mengurangkan penggunaan logam Pt dan Ru.

\section{PENGHARGAAN}

Kajian ini dibiaya dengan Geran Universiti Penyelidikan daripada Universiti Kebangsaan Malaysia di bawah kod geran GGPM - 2017 - 029 dan GUP - $2018-039$.

\section{RUJUKAN}

Ahmad, M.M., Kamarudin, S.K. \& Daud, W.R.W. 2010. Design of an optimal micro direct methanol fuel cell for portable applications. Sains Malaysiana 39(3): 467-472.

Ahmed, K.H. 2015. Applications of nanotechnology in renewable energies-A comprehensive overview and understanding. Renewable and Sustainable Energy Reviews 42: 460-476.

Basri, S., Kamarudin, S.K., Daud, W.R.W. , Yaakob, Z. \& Khadum, A.A.H. 2015. Study on kinetic energy of a novel metal composite for anode catalyst in direct methanol fuel cell. International Journal of Energy Research 39(2): 181-190.

Ferrin, P., Nilekar, A.U., Greeley, J., Mavrikakis, M. \& Rossmeisl, J. 2008. Reactivity descriptors for direct methanol fuel cell anode catalysts. Surface Science 602 (21): 3424-3431

Hongjuan, W., Xiaohui, W., Jiadao, Z., Feng, P. \& Hao, Y. 2014. $\mathrm{Pt} / \mathrm{MoO}_{3}-\mathrm{WO}_{3} / \mathrm{CNTs}$ catalyst with excellent performance for methanol electrooxidation. Chinese Journal of Catalysis 35(10): 1687-1694.

Jiming, L., Yingke, Z., Xiaohui, T., Xiao, X., Hongxi, Z., Shaowei, Z. \& Tao, Y. 2014. Synthesis of boron and nitrogen doped graphene supporting PtRu nanoparticles as catalysts for methanol electrooxidation. Applied Surface Science 317: 284-293.

Hashim, N., Kamarudin, S.K. \& Daud, W.R.W. 2010. Design and development of micro direct methanol fuel cell ( $\mu$ DMFC) for portable application. Sains Malaysiana 39(6): 1015-1023.
Huimin, Y., Baiyan, Z., Bin, Z., Zhe, G. \& Yong, Q. 2018. $\mathrm{N}$-doped carbon modified $\mathrm{Pt} / \mathrm{CNTs}$ synthesized by atomic layer deposition with enhanced activity and stability for methanol electrooxidation. Chinese Journal of Catalysis 39(6): 1038-1043.

Karim, N.A., Kamarudin, S.K., Shyuan, L.K., Yaakob, Z., Daud, W.R.W. \& Khadum, A.A.H. 2014. Novel cathode catalyst for DMFC: Study of the density of states of oxygen adsorption using density functional theory. International Journal of Hydrogen Energy 39(30): 17295-17305.

Liyuan, G., Zhiyuan, Y., Kui, L., Wei, X., Changpeng, L. \& Junjie, G. 2018. Recent development of methanol electrooxidation catalysts for direct methanol fuel cell. Journal of Energy Chemistry 7(6): 1618-1628.

Mustafa, E., Adnan, O., Erol, S. \& Colpan, C.O. 2017. Characterization and performance evaluation of $\mathrm{PtRu} / \mathrm{CTiO} 2$ anode electrocatalyst for DMFC applications. International Journal of Hydrogen Energy 42(33): 21518-21529.

Ozlem, S. \& Hilal, K. 2013. A comparative study of electrochemical methods on Pt-Ru DMFC anode catalysts: The effect of Ru addition. International Journal of Hydrogen Energy 38(2): 901-909.

Prasad, P.P., Datta, M.K., Jampani, P.H., Hong, D., Poston, J.A., Manivannan, A. \& Kumta, P.N. 2015. High performance and durable nanostructured TiN supported Pt50-Ru50 anode catalyst for direct methanol fuel cell (DMFC). Journal of Power Sources 293: 437-446.

Selvarani, G., Vinod, S.S., Krishnamurthy, S., Kiruthika, G.V.M., Sridhar, P., Pitchumani, S. \& Shukla, A.K. 2009. A methanoltolerant-supported Pt-Au alloy cathode catalyst for direct methanol fuel cells and its evaluation by DFT. J. Phys. Chem. C. 113: 7461-7468.

Subhajyoti, S., Kousik, B., Debabrata, P., Biswarup, S. \& Rajendra, S. 2018. Ni and $\mathrm{Cu}$ ion-exchanged nanostructured mesoporous zeolite: A noble metal free, efficient, and durable electrocatalyst for alkaline methanol oxidation reaction. Materials Today Energy 8: 45-56.

Vrushali, S.J., Durgasha, C.P., Ashis, K.S., Kashinath, R.P. \& Santosh, K.H. 2018. Methanol oxidation reaction on Pt based electrocatalysts modified ultramicroelectrode (UME): Novel electrochemical method for monitoring rate of $\mathrm{CO}$ adsorption. Electrochimica Acta 286: 287-295.

Zainoodin, A.M., Kamarudin, S.K., Masdar, M.S., Daud, W.R.W., Mohamad, A.B. \& Sahari, J. 2015. Optimization of a porous carbon nanofiber layer for the membrane electrode assembly in DMFC. Energy Conversion and Management 101: 525-531.

Sahriah Basri* \& Siti Kartom Kamarudin

Fuel Cell Institute

Universiti Kebangsaan Malaysia

43600 UKM Bangi, Selangor Darul Ehsan Malaysia

Siti Kartom Kamarudin

Department of Chemical and Process

Faculty of Engineering \& Built Environment

Universiti Kebangsaan Malaysia

43600 UKM Bangi, Selangor Darul Ehsan

Malaysia

*Pengarang untuk surat-menyurat; email: sahriah@ukm.edu.my

Diserah: 16 November 2018

Diterima: 6 Mac 2019 